\title{
PREDATORY PRICING: SINGLE- FIRM DOMINANCE, EXCLUSIONARY ABUSE AND PREDATORY PRICES (PART 3)
}

\author{
Jan Louis Van Tonder \\ LLB LLM LLM \\ Postgraduate Certificate, Competition Law \\ Postgraduate Diploma, EU Competition Law \\ Postgraduate Diploma, Economics for Competition \\ Law \\ Research Associate, Faculty of Law, Mercantile \\ Law Department, Nelson Mandela University \\ Attorney and Conveyancer of the High Court of \\ South Africa \\ Solicitor of the Senior Courts of England and \\ Wales
}

SUMMARY

Important pronouncements of legal principle were recently made by the Competition Appeal Court and Constitutional Court on the determination of predatory pricing under section 8 of the Competition Act 89 of 1998. These pronouncements must now be seen in the context of the subsequent commencement of the Competition Amendment Act 18 of 2018. In light of these developments, this three-part series of articles evaluate the law relating to the economic concept of predatory pricing under the Competition Act. In this context, the crucial elements of dominance and abuse are also discussed. The first in this series of three articles critically evaluated the law on the determination of single-firm dominance under section 7 of the Competition Act. The second article discussed the basic forms of abuse, the meaning of abuse, tests that have been developed to identify exclusionary conduct, the criticism of the traditional theory of predatory pricing, the main strategic economic theories of predatory pricing and non-pricing theories of predation. This article focuses on the law of predatory prices under section $8(1)(c)$ and $8(1)(d)$ (iv) of the Competition Act. Pursuant to section 1(3) of the Competition Act, when interpreting or applying the Competition Act, appropriate foreign and international law may be considered. This is complementary to section 1(2)(a), which directs that the Competition Act must be interpreted in a manner that is consistent with the Constitution and which gives effect to the purposes set out in section 2. In light hereof and where appropriate, the South African position is mainly compared with the position in the European Union and the United States. 


\section{$1 \quad$ INTRODUCTION}

The broad idea behind predatory pricing is that a dominant firm sets prices for goods or services at such a low level that it deliberately incurs losses or foregoes profits relative to alternative commercial behaviour not involving predatory behaviour. The effect is to exclude or foreclose, or be likely to exclude or foreclose, one or more of the firm's actual or potential competitors. In turn, this allows the firm to strengthen or maintain its market power, thereby causing consumer harm. From an enforcement perspective, an assessment of a predatory pricing case requires a balancing act between over-enforcing the prohibition, which entails the possibility of higher prices for goods and services, and under-enforcing it to the benefit of large firms aiming to strengthen or maintain their market power in the market.

The first two articles in this three-part series focused on the legal analysis of dominance and abuse, respectively. In light of the series of Media24 cases, ${ }^{1}$ the subsequent commencement of the Competition Amendment Act 18 of 2018 (Amendment Act), modern economics and competition law experience in the United States (US) and the European Union (EU), the main aim of this article is to discuss the legal elements of the economic concept of below-cost predatory pricing under the Competition Act 89 of 1998 (the Act). ${ }^{2}$ Discussion under heading 2 concerns the aims and purposes of the Act relative to predatory pricing. Heading 3 discusses the legislative difference in predatory pricing cases falling under section $8(1)(d)($ iv) or $8(1)(c)$. Heading 4 sets out general and specific issues that are usually considered in the identification of a theory of harm based on predatory pricing. Heading 5 discusses the main cost benchmarks used to determine whether a dominant firm has engaged in predatory pricing under section $8(1)(d)$ (iv) or $8(1)(c)$. Heading 6 discusses whether a predatory intention translates into feasibility of excluding competition. Heading 7 provides a conclusion.

\section{AIMS AND PURPOSES OF THE ACT}

The Act recognises that competition between firms is highly desirable. Generally, competition encourages efficiency, innovation, improved product choice and lower prices. ${ }^{3}$ Price competition between firms encourages consumers to switch from their competitors' goods or services to other firms' goods or services. This is regarded as normal competition or competition on the merits. However, the Act also recognises that there is a boundary line when these exceptionally low prices become harmful to competition and

\footnotetext{
Competition Commission of South Africa v Media 24 (Pty) Limited [2019] ZACC 26 (Media24 (CC); Media 24 Proprietary Limited v Competition Commission of South Africa 146/CAC/Sep16 (Media24 (CAC)) and Competition Commission of South Africa v Media 24Limited CT 013938/CR154Oct11 (Media24 (CT)).

2 The article intentionally avoids technical criticisms and debates of complex aspects of predatory pricing, such as how the effect of an alleged predatory price should be determined, what defences the respondent should be allowed to raise, and how the onus of proof should be allocated. Above-cost predatory pricing also falls beyond the ambit of this article.
}

3 S 2 of 89 of 1998 
thus, in the long run, to consumers. This type of below-cost pricing will have the effect of excluding competitors from the market, which increases the likelihood of firms becoming dominant, industry concentration and ultimately the formation of monopolies, which harms consumer welfare.

The Act specifically regulates the behaviour of dominant firms to ensure that they are not abusing their dominant positions to the detriment of competition and consumers. The prohibitions of predatory pricing under section $8(1)(c)$ and (d)(iv) are example of legal instruments used in the ex post regulation of predatory pricing as an exclusionary abuse. Ex post regulation in this context is not an easy task. Approaches to evaluating whether predation has occurred are often criticised as being over-inclusive, in that they implicate innocent firms in predation, or as being under-inclusive, in that they fail to identify firms that are genuinely engaging in predation to the detriment of competition. ${ }^{4}$ Thus, any approach taken to prevent predatory pricing needs to find a balance between over- and underenforcement, while simultaneously fulfilling the purposes of the Act.

Section 2 of the Act envisages this desired balance. While competitive prices and product choices are important, so is the protection of small and medium-sized businesses. Therefore, any approach to prohibiting predatory pricing must avoid over-inclusion as this will harm the ability of firms to set competitive prices, while simultaneously not being under-inclusive as this makes it easy for dominant firms to force small and medium-sized competitors to exit the market.

\section{PREDATORY PRICING UNDER SECTION 8}

Section 8(1)(d)(iv) of the Act sets out a specific prohibition against predatory pricing. In particular, the Amendment Act made changes to section $8(1)$ (d) (iv) by providing that it is prohibited for a dominant firm to sell goods or services at predatory prices. "Predatory prices" means prices for goods or services ${ }^{5}$ below the firm's average avoidable cost or average variable cost. Section $8(1)(d)$ (iv) makes it clear that there are two tests that may be applied in order to determine the existence of predatory pricing - namely, a cost benchmark of average avoidable cost and of average variable cost. Interestingly, before the commencement of the Amendment Act, marginal cost and average variable cost were the relevant cost standards. Shortly before the Act became law, a further influential approach was developed by William Baumol ${ }^{6}$ - namely, the cost benchmark of average avoidable cost. It is probably for this reason that section $8(1)(d)$ (iv) used marginal cost and average variable cost as benchmarks but did not include average avoidable

4 Mackenzie "Are South Africa's Predatory Pricing Rules Suitable?" (September 2014) http://www.compcom.co.za/wp-content/uploads/2014/09/Neil-Mackenzie-Predatory-Pricingin-SA.pdf (accessed 2015-03-22) 3, 5 and 6.

5 S 1 of 89 of 1998 provides that "goods or services", when used with respect to particular goods or services, includes any other goods or services that are reasonably capable of being substituted for them, considering ordinary commercial practice and geographical, technical and temporal constraints.

6 Baumol "Predation and the Logic of Average Variable Cost Test" 199639 Journal of Law and Economics 49. 
cost in the provision at that time. ${ }^{7} \mathrm{~A}$ dominant firm contravenes this section if it charges a price that is below its average avoidable cost or average variable cost, and which has an anti-competitive effect, and if such anticompetitive effect is not outweighed by technological, efficiency or other procompetitive gains.

Section $8(1)(c)$, on the other hand, prohibits unjustified exclusionary acts not listed in section $8(1)(d)$ (iv) that have an overall anti-competitive effect. ${ }^{8}$ In Nationwide Airlines (Pty) Ltd $v$ South African Airways (Pty) Ltd $^{9}{ }^{9}$ the Competition Tribunal said in its interpretation of section $8(1)(d)$ (iv) that its approach is first to limit the scope of the subsection by critically construing any evidence when considering a complaint of predation under that section. Then, unless it is shown unequivocally that the respondent is pricing below the prescribed cost levels, it would not make a finding under section 8(1)(d)(iv) but consider the complaint in terms of section 8(1)(c).

Section $8(1)(c)$ is, therefore, a more expansive catch-all provision in respect of other acts or forms of exclusionary conduct not covered by section 8(1)(d). In Competition Commission of South Africa $v$ Senwes Limited, ${ }^{10}$ the Constitutional Court held that an exclusionary act must fall outside the scope of section $8(1)(d)$ for it to be prohibited by section $8(1)(c)$. It follows that a complaint of predatory pricing brought in terms of section $8(1)(c)$ may not be found on the cost benchmarks prescribed in section $8(1)(d)$ (iv). This also means that other non-pricing forms of predation are captured by section $8(1)(c)$, as opposed to section $8(1)(d)$.

\section{IDENTIFYING THE THEORY OF HARM}

\section{General factors relevant to finding an exclusionary abuse}

In general, the following considerations are relevant when assessing whether a credible theory of harm applies to the conduct of a dominant firm: ${ }^{11}$

(a) the nature and structural features of the market in which the alleged abuse takes place;

(b) the extent to which actual or potential competitors are exposed to the possibility of exclusionary conduct in that market;

Media 24 (CC) supra par 33.

8 Competition Commission of South Africa $v$ Senwes Limited CCT 61/11 [2012] ZACC 6 par 27-28.

9 92/IR/OctOO 10.

10 Supra par 28

11 Bellamy and Child European Union Law of Competition 8ed (2018) 895-896; European Commission Communication - Guidance on the Commission's enforcement priorities in applying Article 82 of the EC Treaty to abusive exclusionary conduct by dominant undertakings [2009] OJ C45/7 (The Guidance Paper) par 20; Case C-413/14 P Intel Corporation Inc. v European Commission EU:C:2017:632 par 136 and see Intel Corporation Inc. $v$ European Commission EU:C:2016:788 par 122-172 of Advocate General Wahl's opinion, which includes detailed discussion of factors relevant in considering an allegation of abuse. 
(c) how far the dominant firm's degree of market power has already weakened competition in the market;

(d) the extent to which the conduct in issue further weakens competition with the dominant firm in the relevant market or strengthens the position of that firm in a connected market;

(e) the direct and indirect effect of the conduct on end-consumers, including, where appropriate, a counterfactual analysis to illustrate the likely impact of the conduct at issue;

(f) how far the conduct reflects a transitory response to a competitive threat as against a systematic attempt (to exclude or discipline competitors) that threatens to impose a long-term impediment to effective competition;

(g) the extent to which a dominant firm can be seen to be "leveraging" its market power in order to place competing firms at a significant disadvantage in parts of the market (or related markets) that are in principle contestable; and

(h) whether the exclusionary effect of the conduct in issue is proportionate to any legitimate commercial interest or, perhaps, public policy objective that may be identified as an "objective justification".

\section{Specific issues relevant in identifying predatory pricing}

A predation case typically involves some combination of the following specific issues: ${ }^{12}$

(a) whether the alleged predator set prices below some relevant measure of cost where these cost tests divide into those where the cost threshold is some type of marginal cost, and those that use some type of average cost that also includes fixed costs/overheads;

(b) whether the alleged predator deviated from short-run profit maximisation while the prey was still in the market, which should include a consideration of the extent to which the alleged predator is treating its customers and competitors less favourably than its own subsidiaries or related companies;

(c) whether there is a realistic possibility that the predator will be able to recoup the cost of predation where the cost of predation can be thought of as actual losses sustained, on a marginal or average cost basis or the "opportunity cost" losses, or profit-sacrifice, compared to the profit that would be achieved under an alternative short-run profit maximisation strategy;

(d) the proportion of customers who are offered lower prices or, stated differently, the proportion of the market that is likely to be foreclosed;

(e) whether there is evidence of predatory intent or whether the dominant firm's conduct constitutes a legitimate and proportionate response to competing firms; and

12 See Media24 (CC) supra; Media24 (CAC) supra; Media24 (CT) supra; Nationwide Airlines v South African Airways (Pty) Ltd [2001] ZACT 1. 
(f) whether the alleged victim of the predatory conduct is as efficient as the alleged predator and, if not, whether the predatory strategy would still have been successful if the prey had been as efficient as the alleged predator.

\section{COST-BASED TESTS FOR PREDATION}

Cost-based tests are the most commonly used indicators in predatory pricing cases to discriminate between competitive price-cutting and unreasonably low prices that are predatory. Since the basic premise is that firms act to maximise profit, these economic cost tests seek to identify the various costs incurred by a firm in producing goods or services and which ultimately determine total revenue. Pricing below a particular cost standard indicates that a firm is not recovering all of the costs incurred in producing a product. The intuition underpinning cost benchmarks could be thought of as a method for identifying pricing at a level that has no legitimate business purpose. In this context, these standards are useful in establishing whether predation has taken place, because they point to a profit sacrifice on the part of the dominant firm.

\section{The principal cost measures under the Act}

There are five cost standards relevant to the determination of predatory pricing under section $8(1)(d)$ (iv) or section $8(1)(c)$ of the Act. They are at the core of the European case law based on AKZO Chemie BV $v$ Commission of the European Communities ${ }^{13}$ and the US approach deriving from the Areeda-Turner test. ${ }^{14}$ These are: (i) marginal cost; (ii) average variable cost; (iii) average avoidable cost; (iv) long-run average incremental cost; and (v) average total cost. As stated, the second and third are the standards applicable to complaints brought under section $8(1)(d)$ (iv), while the remaining three remain relevant to complaints brought under section $8(1)(c)$.

\section{Marginal cost}

Marginal cost is the cost of producing one additional unit of output. Marginal cost is a function of variable costs only, since fixed costs, by definition, do not vary according to output. The marginal cost of a unit of output and the average cost of all units of output can differ.

\section{Average variable cost}

According to section 1 of the Act, "average variable cost" means the "sum of all the costs that vary with an identified quantity of a particular product, divided by the total produced quantity of that product". Examples of variable costs include fuel, electricity, transport, distribution and raw materials.

13 [1991] ECR I-03359.

14 Areeda and Turner "Predatory Pricing and Related Practices Under Section 2 of the Sherman Act" 197588 Harvard Law Review 697. 


\section{Average avoidable cost}

In terms of section 1 of the Act, "average avoidable cost" means the "sum of all costs, including variable costs and product-specific fixed costs, that could have been avoided if the firm ceased producing an identified amount of additional output, divided by the quantity of the additional output". Unlike long-run average incremental cost, this cost measure omits all fixed costs that were already sunk before the time of the predation. Consequently, average avoidable cost will generally be lower than long-run average incremental cost. In sum, average avoidable cost consists of the firm's average variable cost plus fixed costs that would be avoided if the firm ceased production.

\section{Long-run average incremental cost}

Long-run average incremental cost refers to the fixed costs and variable costs a firm incurs when it starts supplying a new product, averaged out over the units of output supplied. It includes all costs that are "incremental" to the production of a particular product. All costs that can be attributed to the relevant product, including any sunk costs of entry, are included under this cost measure, but it excludes all joint or common costs. Therefore, long-run average incremental cost consists of the firm's average avoidable cost plus the sunk costs incurred on entering the market.

This cost measure is often used in the context of regulated network industries, which have high barriers to entry but low operating costs, as it allows firms to average out the high sunk costs that they must recover with the low operating costs.

\section{Average total cost}

Average total cost consists of a combination of variable costs and fixed costs of production, which remain constant irrespective of changes in output, averaged out over the number of units produced. General examples include depreciation, interest and property taxes. Average total cost, therefore, includes long-run average incremental costs plus an allocation of joint and common costs.

\section{The relevant time horizon}

To a large extent, what is variable and what is fixed depends on the time horizon. ${ }^{15}$ Equally, within fixed costs, the time horizon may affect whether a given cost component is viewed as sunk. ${ }^{16}$ The longer the time horizon, the more cost components can be altered and are as such to be regarded as

15 See further O'Donoghue and Padilla Law and Economics of Article 102 TFEU 2ed (2013) 295.

16 O'Donoghue et al Law and Economics of Article 102 TFEU 294. 
variable and avoidable. ${ }^{17}$ In the very short-term, most costs are fixed or sunk. ${ }^{18}$

The implications of using a particular cost measure therefore depend on the time horizon over which they are assessed. Equally, the extent to which predation cases hinge on cost definitions ultimately depends on the relevant time horizon. This raises the question of what the correct time period is over which predation should be assessed. Although there is no widespread agreement on the relevant time period, most commentators agree that the correct period for assessing which costs are variable is the period over which the alleged predatory price(s) prevailed or could reasonably be expected to prevail. ${ }^{19}$ It can be seen that the longer the time horizon over which the profitability of the investment is assessed the more likely it is that predation will be identified.

\section{The principal cost-based tests for predatory pricing}

There is no single cost-based test used by all competition authorities and, as described below, frequently competition authorities have used more than one measure. The most commonly cited approaches are discussed below.

\section{Areeda-Turner test}

Because of the difficulty of assessing the profit-maximising price level, Areeda and Turner argued for the use of marginal cost as the boundary line for determining predatory pricing, rather than the profit-maximising price level. ${ }^{20}$ The Areeda-Turner test relies on marginal cost pricing to differentiate between competitive behaviour and anti-competitive predatory behaviour. ${ }^{21}$ Accordingly, two pricing zones can be distinguished. ${ }^{22}$ First, if a price is below marginal cost, there is a strong presumption of predatory and exclusionary behaviour since losses are made on each unit sold and the predator would make higher profits if it reduced output. ${ }^{23}$ Secondly, if the price is equal to or above marginal cost, there is a presumption of legitimate behaviour, because profits are higher after the last sale compared to a situation of not making that sale at all. ${ }^{24}$

It is well known that the marginal cost of a firm may be difficult to measure. This empirical difficulty in implementing a "pure" Areeda-Turner test also results in an administrative impediment. ${ }^{25}$ For this reason, Areeda

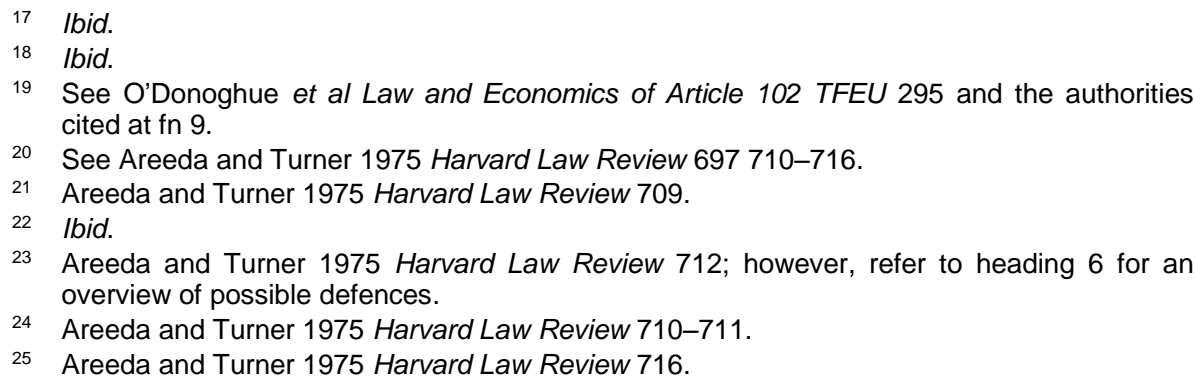


and Turner suggested the use of average variable cost as a surrogate for marginal cost. ${ }^{26}$ This is a good approximation - to the extent that marginal costs are roughly constant over the entire range of output, or if the firm in question produces near the point where average variable cost is at its minimum. ${ }^{27}$ However, this approximation becomes difficult when the line between fixed and variable costs is blurred.

\section{The AKZO test (and its refinement)}

In ECS/AKZO, ${ }^{28}$ the European Commission argued that, apart from the inherent difficulty of accurately establishing costs, a predation test based only on cost does not give sufficient weight to the strategic aspect of a dominant undertaking's price-cutting behaviour. In line with this argument, in its Sixteenth Report on Competition Policy published in 1987, the European Commission set out its policy towards predatory pricing practices. ${ }^{29}$ Their view was that such practices must be considered to be part of an "abusive global strategy" aimed at eliminating other producers in an anti-competitive manner or at restricting their freedom of action. A firm's strategy has many dimensions and price is but one element among many. Consequently, a policy of deterring predatory pricing that does not take account of the context might cause certain firms to have recourse to different methods in order to achieve the same goals. In the ECS/AKZO decision, the European Commission applied this global approach to a strategy that sought to force the exit of a competitor.

On appeal, however, the European Court of Justice adopted a cost-based test approach, ${ }^{30}$ which consisted of two rules. First, prices below average variable cost by means of which a dominant undertaking seeks to eliminate a competitor must be regarded as abusive. The Court of Justice reasoned that since each sale at a price below average variable cost would generate a loss (namely, the total amount of the fixed costs and at least part of the variable costs relating to the unit produced), a dominant undertaking has no interest in applying such prices unless to eliminate competitors so as to enable it subsequently to raise its prices by taking advantage of its position of market power. This rule has been somewhat refined in recent years to recognise the fact that rational business justifications can exist for prices below average variable cost. ${ }^{31}$ Secondly, prices below average total costs, but above average variable costs, must be regarded as abusive if they are determined as part of a plan for eliminating a competitor. The Court of

\footnotetext{
Ibid.

Areeda and Turner 1975 Harvard Law Review 717.
}

28 Case IV/30.698 ECS/AKZO, European Commission Decision of 14 December 1985, OJ L374/1 par 76-77.

29 Commission of the European Communities Sixteenth Report on Competition Policy 1987 par 336.

30 C-62/86 AKZO Chemie BV v Commission of the European Communities [1991] ECR I03359 par $71-72$.

31 Case C-202/07 France Télécom SA v Commission of the European Communities [2009] ECR I-02369 par 109-111; cf. Case C-209/10 Post Danmark A/S v Konkurrencerådet EU:C:2012:172 par 27 where the European Court of Justice said that prices below average variable costs must "in principle" be regarded as abusive. 
Justice reasoned that such prices could drive from the market undertakings that are perhaps as efficient as the dominant undertaking but which, because of their smaller financial resources, are incapable of withstanding the competition waged against them. The extra element of intent is necessary, because reasons do exist, at least in the short-run, for a firm to price a product below average total cost, as opposed to pricing below average variable cost or average avoidable cost.

The Court of Justice adopted the average variable cost threshold of the Areeda-Turner test in its first rule but added another threshold at average total cost to address the scenario where the optimal profit-maximising or loss-minimising prices lie below average total cost and are as such not predatory. However, there are other situations where pricing between average variable cost and average total cost may be predatory - for instance, a profit sacrifice causing exit; the Court of Justice solved this problem in the grey zone between average variable cost and average total cost by looking at the intentions of the alleged predator. If there were evidence of exclusionary intent, then the presumption of legitimacy would cease to apply. In terms of this decision, a plan is usually shown first through direct evidence of intent arising from the dominant firm's documents, and second through indirect factors which, taken together, show an anticompetitive intention underlying the price-cutting.

\section{The European Commission's Guidance Paper}

In its Guidance Paper on enforcement priorities in applying Article 102, the European Commission proposes slightly different cost standards to the two $A K Z O$ rules. Rather than average variable cost, the European Commission uses average avoidable cost as the appropriate benchmark for assessing whether a firm is acting in a predatory manner. ${ }^{32}$

The implication is that if the revenues derived by a firm from a particular activity were less than the costs that the firm would save or avoid if it ceased that activity, then the firm would be better off ceasing the activity. So, if a firm is pricing below average avoidable cost, then it is making short-run losses relative to the alternative of not carrying out the activity at all.

In general, average avoidable costs will be above average variable costs because avoidable costs include fixed costs that are avoided by ceasing an activity. Avoidable costs differ from total costs in that they do not include common costs or costs that are fixed over the relevant time period. Thus, the European Commission will hold that a price below average avoidable cost should be considered as involving a sacrifice of short-run profits and is therefore predatory behaviour. ${ }^{33}$

The adoption of average avoidable costs as a benchmark has two immediate advantages over the use of average variable cost. ${ }^{34}$ First, it avoids the problem of having to achieve a precise distinction between fixed and variable costs within the specific period. Secondly, it provides a more

The Guidance Paper par 64.

33 The Guidance Paper par 64-65.

34 See Baumol 1996 Journal of the Law and Economics 49. 
accurate measure of the avoidable losses than does average variable cost since it also includes the product-specific fixed costs that could be avoided by stopping the production of the product or service in question. As a result, it provides a clear reflection of whether it would be more profitable for the firm to terminate the production than to engage in predatory pricing. ${ }^{35}$ However, average avoidable cost still encounters problems where predation has occurred over a long period of time, and it is difficult to determine which costs are avoidable and which are not. ${ }^{36}$

The European Commission's alternative to average total cost is long-run average incremental cost. ${ }^{37}$ In many cases, long-run average incremental cost will be the same as average total cost. Where they will differ, however, is where a multi-product firm incurs some costs that are common to more than one product. Such costs are not incremental to any one product and so would not be included in long-run average incremental cost. Average total cost, however, typically includes an allocation of such common costs to each product. Where some costs are common across a number of products, there is no single economically correct way to allocate them and it would therefore not seem reasonable to find a firm guilty of predation on the basis that it is pricing below some essentially arbitrary measure of total product cost.

\section{Section 8(1)(d)(iv)}

The Amendment Act added the average avoidable cost measure as the legal test to help distinguish lawful price-cutting behaviour from anti-competitive below-cost pricing. This means that if a dominant firm fails to cover its average avoidable cost or average variable cost, the firm is incurring losses or foregoing profits and may be engaged in unlawful exclusionary conduct. The inclusion of average avoidable cost and average variable cost reflects the discussion above - that is, in most cases these costs will be the same. From an enforcement perspective, in cases where average variable cost and average avoidable cost are the same, the latter better reflects a possible profit sacrifice.

A dominant firm that charges predatory prices below average avoidable cost, but above average variable cost, will now face prosecution under section 8(1)(d)(iv) and not under section $8(1)(c)$, which was the case previously. However, the effect of the predatory pricing strategy will still have to be analysed before an adverse finding can be made. Depending on the situation, both cost measures present some practical difficulties, and the courts have to be practical and choose the test that is better suited to resolve the dispute.

35 See The Guidance Paper par 64 fn 3, where the European Commission writes that in most cases the average variable cost and average avoidable cost will be the same, as often only variable costs can be avoided. However, in circumstances where they will differ, the latter better reflects possible sacrifice.

36 O'Donoghue et al Law and Economics of Article 102 TFEU 305.

37 The Guidance Paper par 67; see also O'Donoghue et al Law and Economics of Article 102 TFEU 307. 


\section{Media24, section 8(1)(c) and the role of intent}

The Competition Commission investigated allegations of predatory pricing against Media24 in 2011 and then referred the complaint to the Competition Tribunal, alleging predatory pricing. The case presented by the Competition Commission was that Media24 had used Forum as a fighting brand. Forum was kept in the market with the sole purpose of charging prices that were lower than its competitors, who were then forced to exit the market. Once this task was completed, the fighting brand closed up shop. Media24 subsequently appealed to the Competition Appeal Court, and then the Competition Commission appealed to the Constitutional Court. The decisions of the Competition Tribunal, ${ }^{38}$ Competition Appeal Court ${ }^{39}$ and the Constitutional Court ${ }^{40}$ primarily dealt with the question of whether pricing below average total cost could be predatory and, if so, under what circumstances, and they included a determination of the role of intent in the analysis.

\section{(i) The Competition Tribunal decision}

The case referred to the Competition Tribunal was based first on an alleged contravention of section $8(1)(d)$ (iv) of the Act, and in the alternative on a violation of section $8(1)(c)$. At that time, section $8(1)(d)$ (iv) still prohibited pricing below marginal cost or average variable cost. The Competition Tribunal found that Media24 had not priced its advertising below its average avoidable cost, and thus the Competition Commission failed to establish that Media24 had priced below the lower standards of average variable cost or marginal cost. ${ }^{41}$ As a result, the Competition Tribunal made its determination using section 8(1)(c) and not section 8(1)(d)(iv).

The Competition Tribunal found that the Competition Commission had established that average total cost was an appropriate cost standard to use to evaluate predation in this case. ${ }^{42}$ In particular, it held that Media24 had charged advertising prices for Forum below its average total cost, that it had intended to predate on GNN, ${ }^{43}$ that Media24 had the ability to recoup what it had lost during this predation period and that GNN had not been excluded owing to its relative inefficiency. It found that Media24's actions had an anticompetitive effect and that there was no evidence of pro-competitive gain that outweighed this effect. ${ }^{44}$ Consequently, the Competition Tribunal found that the Competition Commission had proved that Media24 had priced below

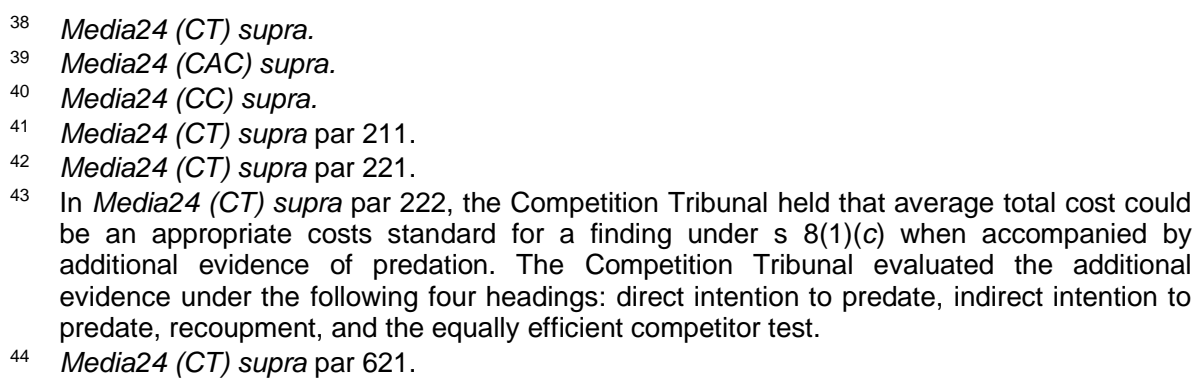


average total cost; this, coupled with "predatory intent", was a contravention of section $8(c)$.

\section{(ii) The Competition Appeal Court decision}

The Competition Appeal Court held that the test envisaged in section 8(1)(c) determines whether specific conduct amounts to an exclusionary act as defined in the Act, and that this is an objective test. The court held that subjective evidence of intent should not be examined in proving predatory pricing. Once such evidence was disregarded, average total cost was not an appropriate cost standard to use to illustrate that predatory pricing occurred. The Competition Appeal Court concluded:

"There is no escaping the conclusion that predation must focus on the likely economic effect of pricing below a particular cost measure to determine whether the low prices are due to a lawful competitive response to rivals or to predation and unlawful behaviour rather than on the intention with which a pricing strategy is adopted." 45

Having rejected using average total cost with intention as the suitable standard, the Competition Appeal Court stated that the only appropriate benchmark that had been relied upon by the Competition Commission in their pleadings was average avoidable cost. The Competition Appeal Court also rejected the Competition Commission's inclusion of hypothetical profits foregone by not pursuing an alternative business strategy. ${ }^{46}$

This does not mean that it is the only appropriate benchmark to apply to section $8(1)(c)$ in all cases, but rather that in this particular case it was the only appropriate test that remained. In light of its rejection of the averagetotal-cost-plus-intent test, the Competition Appeal Court did not have to consider the balance of the evidence concerning the intention of Media24. Accordingly, the appeal by Media24 was upheld as it could not be established that Media24 had violated section 8(1)(d)(iv) or $8(1)(c)$.

\section{(iii) The Constitutional Court decision}

Remarkably, the Constitutional Court decision was decided by 10 judges with four conflicting judgments, which resulted in no majority decision.

The first judgment consisted of three judges. Ultimately, the judgment would grant leave to appeal, uphold the appeal, and remit the matter to the Competition Appeal Court on the basis that the Competition Appeal Court's disregard of the evidence of predatory intent incorrectly limited the powers of the Competition Commission to prosecute matters. They reasoned that the competition authority should be able to use whichever cost benchmark was appropriate for the case at hand, including the average total cost standard when accompanied by sufficient additional evidence.

The second judgment consisted of four judges. Their judgment would dismiss the application for leave to appeal because the assessment of these

45 Media24 (CAC) supra par 56.

46 Media24 (CAC) supra par 109. 
expert economic issues is not appropriate to be determined by the Constitutional Court and gives rise to no constitutional question or a point of law in the public interest.

The third judgment comprised two judges and would grant leave to appeal, but for different reasons to the first judgment. However, they would dismiss the appeal because prohibiting pricing below average total cost would undermine the Act's objectives. They reasoned that unlike a complaint of prohibited predatory pricing pursued against a dominant firm under section 8(1)(d)(iv), the Competition Commission bears the onus under section $8(1)(c)$ to demonstrate that a dominant firm has engaged in an exclusionary act by implementing a predatory pricing strategy. The Competition Commission is, however, afforded significant scope under this catch-all section to advance an appropriate cost standard against which to measure a dominant firm's pricing practices. The court held that in the present matter, the Competition Commission had failed to advance such a test.

The fourth and final judgment of one judge concurred with the third judgment on leave to appeal and the first judgment on the merits.

Considering that the six judges under the first, third and fourth judgments granted leave to appeal, albeit for different reasons, leave to appeal was granted. However, since the six judges responsible for the second and third judgments did not uphold the appeal, again for differing reasons, the appeal was dismissed. This means that the Constitutional Court ultimately dismissed the appeal and that the Competition Appeal Court decision stands. Accordingly, when evaluating whether a firm's prices are below average total cost under section $8(1)(c)$, the role of predatory intent as an indicator to show a contravention is not considered. Equally, since the Amendment Act has amended section 8(1)(d)(iv) by prohibiting pricing below average avoidable cost and average variable cost, this means that the Competition Appeal Court and Constitutional Court decisions stand on the question of pricing below average total cost and the role of intent.

\section{THE ROLE OF INTENT AND FEASIBILITY OF EXCLUSION}

Predation analysis typically centres on the premise that pricing below a certain cost measure is an abuse. The firm appears to incur a loss on each unit sold and the sale therefore would seem to lack any obvious motive other than to drive out a competitor. However, it is widely accepted that there are many legitimate justifications for a firm to choose to price below average total cost, and now above average avoidable cost/average variable cost but below average total cost/long-run average incremental cost. ${ }^{47}$ Some of the individual categories of commercial justification that have a reasonably clear meaning, depending on the circumstances, include introductory pricing and short-run promotions, "option value" systems (for example, "subsidised" printers), two-sided markets (for example, "subsidised" newspapers) and,

47 O'Donoghue et al Law and Economics of Article 102 TFEU 343. 
perhaps, mistake. ${ }^{48}$ In dynamic industries, difficulties exist in distinguishing between investments in economies of scale, network effects, learning by doing, and investments in harming rivals (advantage-building versus advantage-denying). ${ }^{49}$

It might, therefore, be sensible to interpret a dominant firm's motive or predatory intention to be an issue relevant to assessing whether exclusion is feasible, as opposed to trying to second guess a firm's commercial thinking. In this assessment, relevant factors to consider would include whether scale, duration or the firm's low pricing behaviour is likely to have an impact on a competitor. Also, a credible theory of harm that shows that exclusion would be feasible should also show that the conditions are met for the strategic economic theories of predation - for instance, "financial predation" or "signalling theories of predation" - and should further include an analysis of the ease of entry and strength of non-foreclosed competitors.

\section{CONCLUSION}

Firms are thought to engage in predatory pricing exactly because they are not yet able to engage in setting prices above the competitive level. Predation is therefore a means to achieve a position of being able to raise prices by exercising market power. This typically involves sacrificing profits at an initial stage and then recouping the profit sacrifice and profits in excess of that sacrifice at a later stage. The key enforcement difficulty with predation is that it is easily confused with normal competition. A price reduction is not automatically predatory and, in fact, lowering prices can be a direct manifestation of intense competition. Accordingly, care must be applied in analysing predatory pricing cases so as to avoid a signal that prevents dominant firms from lowering their prices to the competitive level for fear of being charged with predatory pricing.

An important debate among lawyers and economists revolves around what the appropriate test is for predation. More precisely, what combination of factors combine to prove a coherent theory of harm based on predation. The legal jurisdictions of the US and EU and their systems of case law, as well as different decision makers within their regulatory agencies, have over time raised various combinations and permutations of requirements and have adopted variants within each condition as constituting proof of predation. Overall, the balance between competition law and economics on predation remains highly contradictory. However, it remains important to develop sound, clear, objective, effective, and administrable predatory pricing rules that enable firms to know in advance whether their price-cutting behaviour will result in liability under section $8(1)(d)$ (iv) or section $8(1)(c)$.

It is suggested that The Guidance Paper's average avoidable cost/longrun average incremental cost version of the Areeda-Turner test is better than the average variable cost/average total cost version. When the predatory increment can be determined, the average avoidable cost measure is the preferred measure in determining whether prices are predatory. Preferably,

48 Ibid.

49 O'Donoghue et al Law and Economics of Article 102 TFEU 352-355. 
only claims involving prices below average avoidable cost, or below a similarly appropriate cost measure, combined with a probability of recoupment, should be subject to potential liability. However, there appears to be no theoretically correct cost benchmark.

On a simple reading of section $8(1)(d)$ (iv), it can be argued that the cost benchmarks of average avoidable cost and average variable cost appears to be better suited for safe harbours than tests of abuse, meaning that belowcost pricing indicates that further investigation may be worthwhile. The benchmarks have importance though in identifying where the hurdle for finding abuse is set. However, ultimately, cost-based tests are form-based tests, and are good for providing safe harbours, but they cannot be used independently of a coherent, fact-based theory of harm to competition. This means that even where prices are below some measure of cost, it does not necessarily imply that this is harmful. The evidence should support that theory to a high-enough standard, especially given the risk that too much intervention means that beneficial price-cutting could be deterred. In the US, the recoupment requirement serves as a valuable screening device to identify implausible predatory-pricing claims.

Under section $8(1)(c)$, and specifically in relation to allegations of prices below average total cost, the courts have clarified that intent plays no role, as such. However, because of the difficulties inherent in all cost standards, it would not be wise for any court to tie itself too closely to any particular cost standard. The ultimate concern in cases such as these should be whether pricing below a cost standard could lead, or led, to the exclusion of a competitor, which exclusion had anti-competitive effects that are not outweighed by the gains listed in section $8(1)(c) .{ }^{50}$ Therefore, consideration should also be given to the feasibility of excluding a competitor and evidence on how prices would increase above the level that otherwise would have prevailed through, for example, the possibility of recouping losses. A consideration of all these factors will help gauge the ultimate issue of what the mechanism for consumer harm is.

50 Media24 (CC) supra par 96 and 71. 